NORMA Volume, No. 1, Juli 2004

\title{
TANGGUNG JAWAB ADVOKAT DALAM MENJALANKAN PROFESI TERHORMAT (OFFICIUM NOBILE)
}

\author{
Oleh
}

\author{
Edi Krisharyanto*
}

\begin{abstract}
ABSTRAK
Meski sebagai profesi terhormat (officium nobile) dan bersedia memberi nasehat dan bantuan hukum kepada orang-orang yang memerlukannya dalam menegakkan hukum, keadilan dan kebenaran namun demikian tuntutan untuk melakukan pekerjaan dengan sikap correct dan sopan serta jujur dan bertanggung jawab melekat pada advokat tersebut agar terhindar jeratan hukum.

Kata kunci : tanggung jawab, officium nobile, legal service.
\end{abstract}

\section{A. PENDAHULUAN}

Perlu diakui bahwa keberadaan advokat dalam kehidupan masyarakat semakin hari semakin menempati posisi yang strategis, apabila dikaitkan dengan kemauan politik dari penguasa untuk mengedepankan hukum (supremasi hukum), dalam hal ini menunjukkan bahwa hukum ditempatkan pada posisi ujung tombak pembangunan dalam negara yang demokratis. Di samping profesi penegak hukum lainnya, advokat juga menjadi harapan dari masyarakat pencari keadilan. Hal ini dengan ditandai telah disetujui dan disahkan Rancangan Undang-Undang menjadi Undang-Undang Advokat oleh Dewan Perwakilan Rakyat Republik Indonesia karena dengan lahirnya undangundang ini akan memperjelas tugas, fungsi dan kedudukan advokat dalam masyarakat, khususnya dalam kaitannya dengan peran Advokat dalam sistem hukum.

- Dosen Fakultas Hukum Universitas Wijaya Kusuma Surabaya 
NORMA Volume, No. 1, Juli 2004

Rancangan Undang-Undang Advoket pekerjaan yang senantiasa dibutuhkan. tersebut telah disahkan pada tanggal Sehingga pada hakekatnya Advokat 6 Maret $2003^{1}$

Dalam hubungannya dengan menjadi profesi sekaligus menjadi mata pencaharian yang memberikan jasa hukum menjalankan peran dan fungsi tersebut, maka advokat sebagai profesi; bebas, mandiri dan bertanggung jawab merupakan hal yang penting, sebab melalui jasa hukum Advokat yang telah diberikan menjadi bagian dari salah satu unsur dalam sistem peradilan. Sehingga dalam menegakkan hukum dan keadilan advokat bebas mengeluarkan pendapat atau pernyataan dalam membela perkara yang menjadi tanggung jawab di dalam sidang pengadilan dengan tetap berpegang pada kode etik profesi dan peraturan perundang-undangan, dengan demikian meskipun ada kebebasan dalam menjalankan profesi, namun tetap diwajibkan menghormati kode etik dan peraturan perundang-undangan.

Seiring dengan perkembangan peradaban manusia, yang ditandai dengan perkembangan dari berbagai sektor seperti perdagangan, industri dan jasa, maka pekerjaan pembelaan lalu menjadi

1 Frans H. Winarta, Kemandirian Advokad Dalam undang-Undang Advokad, Bahan Seminar, 12 April 2003, Surabaya

(legal service) kepada para pencari keadilan dengan mendapatkan imbalan.

Disisi lain, dalam Undang-Undang Profesi Advokat ditegaskan bahwa profesi advokat tidak dapat digugat secara perdata maupun dituntut secara pidana ketika menjalankan profesinya dengan itikad baik untuk pembelaan klien dalam sidang pengadilan. Namun demikian dalam praktek bila seorang advokat terbukti melakukan pelanggaran terhadap kode etik maupun pelanggaran hukum, maka Dewan Kehormatan Organisasi Advokat membentuk Majelis yang susunannya terdiri dari unsur Dewan Kehormatan, para pakar atau tenaga ahli bidang hukum dan tokoh masyarakat dapat menindaknya.

Hal tersebut dalam kenyataan bahwa profesi advokat dapat digugat maupun dituntut atas pekerjaan yang sedang dilaksanakan, bila ada kerugian maupun ada unsur pidana terhadap kliennya, sebagai contoh yaitu kasus Juan Felix Tampubolon seorang Advokat yang, 
NORMA Volume, No. 1, Juli 2004

Rancangan Undang-Undang Advoket pekerjaan yang senantiasa dibutuhkan. tersebut telah disahkan pada tanggal 6 Maret $2003^{1}$

Dalam hubungannya dengan menjalankan peran dan fungsi tersebut, maka advokat sebagai profesi; bebas, mandiri dan bertanggung jawab merupakan hal yang penting, sebab melalui jasa hukum Advokat yang telah diberikan menjadi bagian dari salah satu unsur dalam sistem peradilan. Sehingga dalam menegakkan hukum dan keadilan advokat bebas mengeluarkan pendapat atau pernyataan dalam membela perkara yang menjadi tanggung jawab di dalam sidang pengadilan dengan tetap berpegang pada kode etik profesi dan peraturan perundang-undangan, dengan demikian meskipun ada kebebasan dalam menjalankan profesi, namun tetap diwajibkan menghormati kode etik dan peraturan perundang-undangan.

Seiring dengan perkembangan peradaban manusia, yang ditandai dengan perkembangan dari berbagai sektor seperti perdagangan, industri dan jasa, maka pekerjaan pembelaan lalu menjadi

1 Frans H. Winarta, Kemandirian Advokad Dalam undang-Undang Advokad, Bahan Seminar, 12 April 2003, Surabaya

Sehingga pada hakekatnya Advokat menjadi profesi sekaligus menjadi mata pencaharian yang memberikan jasa hukum (legal service) kepada para pencari keadilan dengan mendapatkan imbalan.

Disisi lain, dalam Undang-Undang Profesi Advokat ditegaskan bahwa profesi advokat tidak dapat digugat secara perdata maupun dituntut secara pidana ketika menjalankan profesinya dengan itikad baik untuk pembelaan klien dalam sidang pengadilan. Namun demikian dalam praktek bila seorang advokat terbukti melakukan pelanggaran terhadap kode etik maupun pelanggaran hukum, maka Dewan Kehormatan Organisasi Advokat membentuk Majelis yang susunannya terdiri dari unsur Dewan Kehormatan, para pakar atau tenaga ahli bidang hukum dan tokoh masyarakat dapat menindaknya.

Hal tersebut dalam kenyataan bahwa profesi advokat dapat digugat maupun dituntut atas pekerjaan yang sedang dilaksanakan, bila ada kerugian maupun ada unsur pidana terhadap kliennya, sebagai contoh yaitu kasus Juan Felix Tampubolon seorang Advokat yang 
menjadi tersangka karena dianggap menghalang-halangi proses penggeledahan di rumah Hutomo Mandala Putra oleh Polda Metro Jaya dan kepadanya dikenai jeratan pasal 216 KUHP ayat 1 . Hal ini juga menimpa mantan kuasa Hukum Tomy Soeharto, Elsyza Syarif, ia menjadi tersangka kasus Penyuapan dua Satpam Apartemen Cemara, yang dikenai jeratan pasal 242 KUHP Jo pasal 55 dan UndangUndang Nomor 11 Tahun $1980 .^{2}$ Sehingga posisi Advokat antara undang-undang Advokat dengan kenyataan yang terjadi ada perbedaan.

\section{B. PERMASAlahaN}

Dari uraian tersebut diatas maka dapat dirumuskan dalam suatu permasalahan sebagai berikut : Bagaimana tanggung jawab Advokat dalam kaitannya menjalankan profesi ?

\section{PEMBAHASAN}

\section{a. Pertanggungjawaban Pidana}

Dalam hal pertanggung jawaban pidana, ada dua aliran yang

2 Harian Pagi Jawa Pos, Jum'at tanggal 21 Februari 2003 h.3 berkembang. Yaitu aliran monistis dan aliran dualisme terhadap delik, kedua aliran ini menyatakan bahwa terbuktinya perbuatan aktif / pasif yang dilarang atau diperintahkan oleh perundang-undangan pidana adalah merupakan Conditio Sine Quanon untuk penjatuhan pidana.

Mewurut Simons, yang dikenal dengan Aliran Monisme, merumuskan Strafbaar feit adalah sebagai berikut :

"eene strafbaar gestelde, onrechtmatige, met schuld in verband staande handeling van een toerekening vatbaar persoon" (suatu perbuatan yang oleh hukum diancam dengan hukuman, bertentangan dengan hukum, dilakukan seorang yang bersalah dan orang itu dianggap bertanggungjawab atas perbuatannya). ${ }^{3}$

Menurut aliran monisme tersebut diatas maka unsur-unsur strafbaar feit meliputi: unsur perbuatan, yang disebut unsur obyektif, dan unsur pembuat, yang disebut unsur subyektif. Oleh karena itu dicampurnya unsur perbuatan dan unsur pembuatnya, maka
3 Simons dalam Abidin Faried, Bunga Rampai Hukum Pidana, Pradnya Paramita, Jakarta, 1983, h.194. 
dapat disimpulkan bahwa strafbaar feit sama dengan syarat-syarat penjatuhan pidana, sehingga seolah-olah dianggap kalau terjadi strafbaar feit, maka pasti pelakunya dapat dipidana.

Aliran Monistis memandang unsur pembuat delik sebagai bagian strafbaar feit. Sehingga, penganut aliran monistik tentang strafbaar feit atau "criminal act" berpendapat, bahwa unsur-unsur pertanggung jawaban pidana yang menyangkut pembuat delik meliputi,: ${ }^{4}$

a. Kemampuan bertanggungjawab;

b. Kesalahan dalam arti luas; sengaja dan / atau kealpaan;

c. Tidak adanya alasan pemaaf (verontschuldigingsgronden)

Sebaliknya, apabila dianut aliran dualistis mengenai delik, maka unsurunsur pembuat yang merupakan pertanggung jawaban pidana bahwa pembuat, tidak termasuk unsur delik. Orang pertama yang menganut aliran dualistis tentang delik adalah Herman Kontorowics, sarjana hukum Jerman yang ajarannya diperkenalkan dan dianut oleh Moeljanto. Herman Kontorowics memperkenalkan ajaran tentang "subjective schuld" sebagai pengganti paham "objective schuld" yang banyak dianut. Untuk adanya "strafvoraussetgungen" (syarat-syarat penjatuhan pidana terhadap pembuat), diperlukan lebih dahulu pembuktian adanya strafbaar handlung (perbuatan pidana), lalu sesudahnya itu dibuktikan "schuld" atau kesalahan subyektif pembuat.

Moeljatno $^{5}$ mengemukakan

bahwa :

Perbuatan pidana hanya menunjuk kepada dilarang dan diancamnya perbuatan dengan suatu pidana. Apakah orang yang melakukan perbuatan kemudian juga dijatuhi pidana, sebagaimana telah diancamkan, ini tergantung dari soal apakah dalam melakukan perbuatan ini dia mempunyai kesalahan, sebab azas dalam pertanggung jawaban dalam hukum pidana adalah : tidak dipidana jika tidak ada kesalahan (Geen Straf Zonder Schuld; Actus non facit reun nisi mens sit rea). Azas ini tidak tersebut dalam hukum tertulis tapi dalam hukum yang tidak tertulis, yang di Indonesia juga berlaku.

${ }^{5}$ Moeljatno, Azas- Azas Hukum Pidana, Gajah Mada University Press, Yogyakarta, 1982, h.104

${ }^{4}$ Ibid, h.46. 


\section{Sehingga dapat dinyatakan} bahwa orang tidak mungkin dapat dipertanggung jawabkan pidana (dijatuhi pidana) kalau tidak melakukan perbuatan pidana. Tetapi kendatipun melakukan perbuatan pidana, tidak selalu dia dapat dipidana, kecuali jika perbuatan tersebut dapat dipersalahkan kepadanya. Di sini berlaku apa yang disebut asas "Tiada pidana tanpa kesalahan" (Keine Straffe Ohne Schuld atau Geen Straf Zonder Schuld).

Dalam aliran dualistis, memisahkan "perbuatan pidana" dan "pertanggung jawaban pidana" ini dipakai dalam sistem KUHP yang baru. Yang kemukakan oleh Barda Nawawi Arief $^{6}$ dalam mengetengahkan beberapa aspek "baru" dalam rancangan KUHP 1991 / 1992 nantinya, adalah sebagai berikut :

Bertolak dari pemikiran demikianlah, maka dalam Konsep Buku II ada bab tersendiri mengenai : tindak pidana dan pertanggung jawaban pidana" (Bab II). Bertolak dari pembagian sistematik antara "tindak pidana" dan "pertanggung jawaban pidana"

6 Barda Nawawi Arief, Bunga Rampai Kebijakan Pidana, Citra Aditya Bakti, Bandung, 1996, h. 50 maka di dalam Bab II dipisahkan pasal-pasal mengenai "tindak pidana dengan pasal-pasal kesalahan".

Bahwa sistem KUHP yang baru akan mengacu pada aliran dualistis dalam pertanggungjawaban pidana. Yang terbukti adanya pemilahan pasalpasal antara "perbuatan pidana" dari pasal-pasal "kesalahan" dalam konsep baru KUHP, sehingga dengan aliran dualistis tersebut maka akan meringankan tugas hakim untuk melakukan sistematika unsur-unsur dari suatu tindak pidana yang masuk dalam perbuatan, dan unsur-unsur yang masuk dalam pertanggung jawaban (kesalahan).

Rumusan kesalahan dalam KUHP lama masih terintegrasi dalam rumusan perbuatan pidana. Sehingga kesalahan dalam ketentuan pidana dirumuskan dalam "kesengajaan/ kelalaian", bukan merupakan unsur perbuatan pidana, akan tetapi merupakan bagian dari ajaran kesalahan (pertanggung jawaban). Dapat diartikan pula bahwa: perbuatan pidana menjadi bagian dari ajaran mengenai azas legalitas, sedangkan kesengajaan/ 
kelalaian merupakan bagian dari ajaran mengenai kesalahan.

Mengenai azas tindak pidana tanpa kesalahan diatas tersebut dapat dilihat pada pasal 6 ayat (2) UndangUndang No. 14 Tahun 1970 tentang Pokok-Pokok Kekuasaan Kehakiman menegaskan :

Tiada seorangpun dapat dijatuhi pidana kecuali apabila pengadilan karena alat pembuktian yang sah menurut undang-undang mendapat keyakinan, bahwa seseorang yang dapat dianggap bertanggung jawab telah bersalah atas perbuatan yang dituduhkan atas dirinya.

Dari ketentuan bunyi pasal tersebut menunjukkan bahwa unsur kesalahan sangat menentukan akibat perbuatan seseorang, yakni berupa penjatuhan pidana. Hal ini sejalan dengan pendapat Sudarto $^{7}$ yang menyatakan sebagai berikut :

Untuk adanya pemidanaan harus ada kesalahan pada si pembuat. Asas tiada pidana tanpa kesalahan mempunyai sejarahnya sendiri. Dalam ilmu hukum pidana dapat dilihat pertumbuhan dari hukum pidana yang menitikberatkan kepada perbuatan orang beserta akibatnya

7 Sudarto, Hukum dan Perkembangan Masyarakat, Sinar Baru, Bandung, 1983, h. 85
(Tatstrafrecht atau Erfolgstrafrecht) ke arah hukum pidana yang berpijak pada orang yang melakukan tindak pidana (Taterstrafrecht), tanpa meninggalkan sama sekali sifat dari Tatstrafrecht. Dengan demikian hukum pidana yang ada dewasa ini dapat disebut "Tat-Taterstrafrecht", ialah hukum pidana yang berpijak pada perbuatan maupun orangnya. Hukum pidana dewasa ini dapat pula disebut sebagai Schuldstrafrecht, artinya bahwa unsur penjatuhan pidana disyaratkan adanya kesalahan pada si pembuat.

Dari pendapat tersebut, maka terhadap orang yang melakukan perbuatan pidana akan dipidana, apabila ia mempunyai kesalahan. Bagaimana orang dapat dikatakan mempunyai kesalahan? Hal inilah yang dibicarakan dalam pertanggung jawaban pidana.

\section{Roeslan $\mathrm{Saleh}^{8}$ berpendapat} bahwa seseorang mempunyai kesalahan apabila pada waktu melakukan perbuatan pidana, dilihat dari segi masyarakat dia dapat dicela oleh karenanya, sebab dia dianggap dapat berbuat lain, jika memang tidak ingin berbuat demikian. Ditegaskan bahwa:

8 Roeslan Saleh, Perbuatan pidana dan Pertanggungjawaban Pidana, Dua Pengertian 
Dilihat dari segi masyarakat ini menunjukkan pandangan yang normatif mengenai kesalahan. Seperti diketahui mengenai kesalahan ini dulu orang berpendapat psychologisch. Demikian misalnya pandangan dari pembentuk W.V.S. Tetapi kemudian pandangan ini ditinggalkan orang dan orang lalu berpandangan normatif. Ada atau tidaknya kesalahan tidaklah ditentukan bagaimana keadaan senyatanya batin daripada terdakwa, tetapi tergantung pada bagaimanakah pengalaman hukum, mengenai keadaan batinnya itu, apakah dipernilai ada ataukah tidak ada kesalahan.

Menurutnya bahwa orang dapat dikatakan mempunyai kesalahan bila pada waktu melakukan perbuatan pidana, dilihat dari segi masyarakat dapat dicela, yaitu kenapa melakukan perbuatan yang merugikan masyarakat, sementara ia dapat mengetahui arti (jelek) perbuatan tersebut, dan dapat menghindari untuk berbuat demikian.

Sedangkan menurut Sudarto ${ }^{9}$ bahwa unsur kesalahan mengandung pengertian kesalahan psychologis dan kesalahan dalam arti normatif, yaitu :
Pengertian kesalahan yang psikologis bahwa kesalahan hanya dipandang sebagai hukum psikologis (batin) antara si pembuatan dan perbuatannya. Hubungan batin tersebut bisa berupa kesengajaan atau kealpaan: pada kesengajaan hubungan batin itu berupa menghendaki (beserta akibatnya) dan pada kealpaan tidak ada kehendak demikian. Jadi di sini hanya digambarkan keadaan batin si pembuat, sedangkan yang menjadi ukurannya adalah sikap batin yang berupa kehendak terhadap perbuatan atau akibat perbuatan. Sedangkan pengertian kesalahan yang normatif, menentukan kesalahan seseorang tidak hanya berdasarkan sikap batin atau hubungan batin antara pembuat dan perbuatannya, tetapi disamping itu harus ada unsur penilaian atau unsur normatif perbuatannya. Penilaian normatif artinya penilaian dari luar mengenai hubungan antara pembuat dengan perbuatannya. Penilaian dari luar ini merupakan pencelaan dengan memakai ukuran-ukuran yang terdapat dalam masyarakat, ialah apa yang seharusnya diperbuat oleh si pembuat. Di dalam pengertian-pengertian ini sikap batin si pembuat adalah berupa kesengajaan dan kealpaan tetap diperhatikan, tetapi hanya merupakan unsur dari kesalahan atau unsur dari pertanggungjawaban pidana. Disamping itu ada unsur lain ialah penilaian mengenai

Dasar Dalam Hukum Pidana, Aksara Baru Jakarta, 1983, h.77

$9 \quad$ Ibid, h.89 
keadaan jiwa si pembuat, ialah kemampuan bertanggungjawab dan tidak adanya penghapus kesalahan.

Menurut Pompe ${ }^{10}$ bahwa kesalahan dapat dicela (verwiftbaarheid) dan yang dapat dihindari (vermijtbaarheid) perbuatan yang dilakukan, yaitu:

Menurut akibatnya, hal ini adalah dapat dicela, menurut hakikatnya dia adalah dapat dihindari kelakuan yang melawan hukum itu. Karena kehendak si pembuat itu terlihat pada kelakuan yang bersifat melawan hukum, maka ini dapat dicelakan padanya. Sampai sekian jauh maka kesalahan menyebabkan atau mempunyai akibat dapat dicela. Celaan ini dimungkinkan karena si pembuat itu bisa berusaha, agar tidak berbuat berlawanan. Pelanggaran atas norma itu bergantung pada kehendaknya itu dapat dihindarinya. Sampai sekian jauhnya kesalahan berarti atau hakikatnya adalah dapat dihindari.

Dari uraian tersebut, hakikat kesalahan menurut Pompe adalah dapat dihindarinya perbuatan yang bertentangan dengan hukum oleh pembuat, atau bahwa pada dasarnya pembuat dapat bertindak lain jika perbuatan yang bertentangan hukum itu tidak dikehendaki.

Kesalahan merupakan keadaan jiwa dari si pembuat dengan perbuatannya. Bila terdapat kesalahan pada seseorang, maka seseorang itu dapat dicela, sedangkan, mengenai keadaan jiwa dari seseorang yang melakukan perbuatan merupakan apa yang lazim disebut sebagai kemampuan bertanggung jawab, sedangkan hubungan batin antara si pembuat dengan perbuatannya itu merupakan alasan pemaaf. Dengan demikian, untuk menentukan adanya kesalahan seseorang harus memenuhi beberapa unsur.

Ada tiga unsur kesalahan menurut Soedarto ${ }^{11}$ yaitu: Adanya kemampuan bertanggungjawab pada si pembuat;

a. Hubungan batin antara si pembuat dengan perbuatannya yang merupakan kesengajaan (dolus) atau kealpaan (culpa) ini disebut bentukbentuk kesalahan;

b. Tidak adanya alasan penghapus kesalahan atau tidak ada alasan pemaaf.

${ }^{10}$ Roeslan Saleh, loc. cit

1 Sudarto, op. cit., h.91 
Menurutnya, bahwa ketiga unsur diatas merupakan kesatuan yang tidak dapat dipisah-pisahkan. Karena antara yang satu dengan yang lain saling bergantung dan urutannya tidak dapat dibolak balik. Kenyataannya bahwa tidak mungkin dipikirkan tentang kesengajaan atau kealpaan, apabila orang itu tidak mampu bertanggung jawab. Atau bahwa tidak dapat dipikirkan mengenai alasan pemaaf, apabila orang tidak mampu bertanggung jawab dan tidak adanya kesengajaan atau kealpaan. Sehingga tidak ada gunanya untuk mempertanggungjawabkan terdakwa atas perbuatannya apabila perbuatan itu sendiri tidak bersifat bertentangan dengan hukum, maka dapat dimengerti bahwa terlebih dahulu harus ada kepastian tentang perbuatan pidana, dan kemudian semua unsur kesalahan dapat dikaitkan dengan perbuatan pidana yang diperbuat.

Dari uraian tersebut, dapat dijelaskan pula bahwa kesalahan seseorang dapat dipidana, yaitu bila :

a. Telah melakukan perbuatan hukum; b. Orang tersebut telah mampu bertanggungjawab;

c. Perbuatannya dilakukan dengan adanya kesengajaan atau kealpaan;

d. Semua yang termaktub dalam butir a s/d c tersebut dilakukan dengan tiadanya alasan pemaaf.

Dalam pasal 44 KUHAP, bahwa kemampuan bertanggung jawab tidak diberikan rumusan apapun, namun ketentuan tersebut menuju adanya kemampuan bertanggung jawab, yaitu :

'"Barang siapa melakukan perbuatan yang tidak dapat dipertanggung jawabkan kepadanya karena jiwanya cacat dalam pertumbuhan atau tertanggung karena sakit, tidak dipidana."

Dari ketentuan pasal di atas dapat dijelaskan bahwa kemampuan bertanggung jawab menunjuk pada kondisi kejiwaan dari si pembuat, karena kejiwaan ini merupakan konstruksi dari normalitas jiwa si pembuat saat melakukan tindak pidana, sehingga secara wajar ia dapat menilai pada perbuatannya sendiri (perbuatan tercela atau tidak).

Di sisi lain konstruksi pertanggungjawaban (kesalahan) 
merupakan hubungan batin antara pembuat dengan perbuatannya. Hal ini terwujud dalam unsur kesengajaan (dolus) dan kealpaan (culpa).

Dalam hukum pidana ada dua macam teori yang berkaitan dengan keadaan batin seseorang yang berbuat sengaja, baik menghendaki atau mengetahui, yaitu: ${ }^{12}$

a. Teori Kehendak (wilstheori) dari Von Hippel. Sengaja menurut Von Hippel adalah kehendak membuat suatu tindakan dan kehendak menimbulkan suatu akibat karena tindakan itu. Dengan kata lain "sengaja" adalah apabila akibat suatu tindakan dikehendaki, apabila akibat itu menjadi maksud benarbenar dari tindakan yang dilakukan tersebut.

b. Teori membayangkan (voorstellings-theori), dari Frank. Menurutnya berdasarkan suatu alasan psikologis maka tidak mungkinlah suatu hal "akibat" dapat dikehendaki. Manusia hanya dapat menghendaki suatu tindakan, manusia tidak mungkin menghendaki suatu akibat, manusia hanya dapat menginginkan, mengharapkan atau membayangkan (voorstellen) kemungkinan adanya suatu "akibat". Rumus Frank menyatakan : adalah sengaja, apabila suatu akibat (yang ditimbulkan karena suatu tindakan) dibayangkan sebagai maksud (tindakan itu) dan oleh sebab itu tindakan yang bersangkutan dilakukan sesuai dengan bayangan yang lebih dulu telah dibuat tersebut.

\section{Sehubungan dengan teori} tersebut, menurut Sodarto ${ }^{13}$ bahwa kedua teori tersebut tidak memiliki perbedaan. Sebab kedua teori tersebut menjelaskan bahwa dalam kesengajaan harus ada kehendak berbuat. Sedangkan yang membedakan diantaranya yaitu bahwa dalam hal kesengajaan terdapat adanya unsur lain dari delik, sebagai contoh yaitu akibat dan keadaan yang menyertainya. Dari dua teori tersebut, maka teori yang satu menyebutkan "menghendaki", dan teori yang lain menyebutkan "mengetahui atau membayangkan".

Namun demikian dalam kenyataannya penggunaan terhadap hasil kedua teori adalah sama. Hanya yang membedakannya adalah pada masalah terminologi, dalam istilah saja.

12 Muladi dan Dwija Priyatno, 
Menurut Van $\mathrm{Hamel}^{14}$ ada dua syarat untuk adanya kealpaan, yaitu:

a. Tidak mengadakan penduga-duga sebagaimana diharuskan oleh hukum;

b. Tidak mengadakan penghati-hati sebagaimana diharuskan oleh hakim.

Syarat yang pertama, terdapat hubungan batin antara pembuat dengan akibat yang timbul karena perbuatannya, atau keadaan yang menyertainya. Sehingga perbuatan yang dilakukan terdakwa itu seharusnya dapat dihindarkan, karena seharusnya ia menduga lebih dulu bahwa perbuatan itu dapat menimbulkan akibat yang dilarang.

\section{b. Pengertian dan Kedudukan Advokat}

Pengertian Advokat dalam undang-undang yang baru (UU No. 18 / 2003, pasal 1 ayat 1), adalah orang yang berprofesi memberi jasa hukum, baik di dalam maupun diluar pengadilan yang memenuhi persyaratan berdasarkan ketentuan undang-undang ini. Dari pengertian ini memberikan

14 Muladi dan Dwija Priyatno, op.cit., h.64 makna bahwa dalam proses peradilan profesi advokat memiliki peranan dan kedudukan yang sama dengan penegakpenegak hukum yang lainnya.

$\begin{array}{ccr}\text { Advokat } & \text { juga } & \text { bebas } \\ \text { mengeluarkan } & \text { pendapat atau }\end{array}$
persyaratan dalam membela perkara yang menjadi tanggung jawabnya di dalam sidang pengadilan dengan tetap berpegang pada kode etik profesi dan peraturan perundangan yang berlaku.

Dalam menjalankan profesi pembelaan perkara, yang dimaksudkan dengan pemberian jasa adalah jasa yang diberikan kepada advokat yang berupa memberikan konsultasi hukum, bantuan hukum, menjalankan kuasa, mewakili, mendampingi, membela dan melakukan tindakan hukum lain untuk kepentingan hukum klien.

Sedangkan menurut Adnan Buyung Nasution ${ }^{15}$ Advokat adalah identik dengan istilah pengacara atau penasehat hukum, padahal dalam dunia 
hukum tidak dikenal nama pengacara atau penasehat hukum.

Ada beberapa istilah yang digunakan pada negara-negara yang menganut Sistem Hukum Eropa Continental atau Civil Law, seperti : Belgia, Belanda, Italia, Spanyol maupun bekas jajahannya termasuk Indonesia, istilah yang dipakai adalah Advokat.

Berbeda dengan negara-negara menganut sistem Anglo Saxon, misalnya : Amerika Serikat, Inggris, Kanada termasuk Singapura dan Malaysia. Istilah yang dipakai adalah : Barrister, Solicitor atau Attorney at Law. Sedangkan istilah pengacara atau Procureur $^{16}$ adalah menggambarkan sifat pekerjaan atau salah satu bidang pekerjaan saja dari profesi Advokat yaitu yang menyangkut beracara di pengadilan. Untuk penasehat hukum ataupun konsultan hukum dua istilah ini menunjukkan bidang atau bagian dari jasa yang diberikan oleh Advokat dalam menjalankan profesinya.
Dari uraian pengertian tersebut di atas menunjukkan bahwa profesi Advokat merupakan profesi yang usianya sama dengan profesi dokter, sebab kedua profesi ini bersumber pada keinginan yang sama, yaitu panggilan nurani dalam kaitannya untuk menolong sesama manusia yang sedang mengalami penderitaan atau musibah hukum atau penyakit yang dideritanya.

Pemberian pertolongan bukan karena kepentingan atau kebutuhan akản uang semata melainkan oleh karena adanya dorongan keinginan hati untuk menolong atau membantu secara ikhlas.

Seiring dengan perkembangan dunia, bahwa telah terjadi perkembangan di berbagai sektor, baik di bidang industri maupun jasa. Termasuk jasa pembelaan dan pendampingan di pengadilan menjadi pekerjaan tetap. Dapat disimpulkan bahwa Advokat menjadi profesi sekaligus mata pencaharian yang memberikan jasa-jasa hukum (legal services) kepada para pencari keadilan

16 Ibid., h. 
atau klien dengan menerima imbalan jasa atau honorarium.

\section{Memperhatikan pengertian} honorarium sebagai imbalan atas jasa hukum yang diterima oleh Advokat berdasarkan kesepakatan dengan klien, hal ini menunjukkan bahwa advokat sebagai pemberi jasa hukum bukanlah melakukan dagang perkara yang dapat ditawar-tawar akan tetapi memberikan jasanya dan sebagai penghormatan atas jasa yang telah diberikan, maka advokat menerima imbalan atas jasa yang telah diberikan yang juga disebut sebagai honorarium.

Dari uraian tanggung jawab pidana advokat dalam kaitannya dengan perbuatan yang dilakukan dalam kaitan dengan pemberian jasa hukum dan kedudukan Advokat sebagai subyek hukum di atas, maka menurut hemat saya perlu diperhatikan untuk menyatakan bersalah atau tidaknya advokat dalam menjalankan profesinya, yaitu sebagai berikut :

Pertama, kapan seorang advokat sebagai subyek hukum dapat bertanggung jawab terhadap perbuatan yang telah dilakukannya, hal ini terkait dengan kapan seorang Advokat telah melakukan perbuatan pidana.

Kedua, apakah perbuatan dari subyek hukum tersebut meliputi unsurunsur: kemampuan bertanggung jawab, ada kesalahan dalam arti luas (kesengajaan atau kelalaian) dan tidak adanya alasan pemaaf.

Dalam permasalahan ini pertanggungjawaban dapat dibedakan dari perbuatan pidana (delik), karena perbuatan pidana hanya menunjuk pada dilarangnya perbuatan.

Ketiga, apakah orang yang telah melakukan perbuatan itu kemudian dipidana, hal ini tergantung pada perbuatan yang dilakukan itu mempunyai kesalahan atau tidak, tetapi bila ia tidak mempunyai kesalahan walaupun ia melakukan perbuatan yang dilarang dan tercela tentu tidak dipidana.

Dan dalam konteks tanggung jawab, maka ada tiga sanksi yang dapat dibebankan bila seorang Advokat melakukan pelanggaran maupun 
kelalaian dalam menjalankan tugas yaitu :

Pertama, Sanksi Administrasi, yaitu berupa : peringatan, teguran, skors dan atau pemecatan dari profesi, hal ini tentunya melalui mekanisme dari keputusan asosiasi profesi.

Kedua, Sanksi Perdata, yaitu berupa : gugatan wanprestasi, dengan konsekwensi untuk memenuhi suatu prestasi yang telah disepakati maupun gugatan ganti rugi yang diakibatkan dari perbuatan dalam menjalankan profesi yang menimbulkan kerugian, dasar hukum gugatan ganti rugi pada pasal 1365 Kitab Undang-Undang Hukum Perdata.

Ketiga, Sanksi Pidana, yaitu atas perbuatannya dalam menjalankan profesi yang telah menimbulkan dan akibat kejahatan maupun pelanggaran. Dengan macam sanksi yang tertuang dalam pasal 10 Kitab Undang-Undang Hukum Pidana.

Dari uraian tersebut diatas maka setiap profesi apapun termasuk penegak hukumpun dapat diminta pertanggung jawaban terhadap pekerjaan atau profesi yang telah dilakukannya.

\section{PENUTUP}

Bagian ini merupakan bagian terakhir yang berisi kesimpulan atas jawaban dari permasalah yang diangkat dalam tulisan ini : Bagaimana tanggung jawab Pidana Profesi Advokat dalam Menjalankan Profesi dan saran yang merupakan usulan praktis dalam rangka mewujudkan adanya keadilan, kebenaran, kepastian hukum dan supremasi hukum dalam kehidupan masyarakat.

1. Simpulan

Dari uraian pembahasan diatas, maka dapat disimpulkan halhal sebagai berikut :

Bahwa meskipun sanksi pidana secara eksplisit tidak dicantumkan dalam undang-undang ini, namun sebagai subyek hukum dalam menjalankan profesi seorang advokat dapat dimintakan pertanggung jawaban secara pidana. Dan tentunya akan ditentukan terlebih dahulu adalah pelanggaran 
dari sisi etik profesi dihadapan

Majelis Kehormatan Kode Etik.

2. Saran

Advokat hendaknya dapat

mewujudkan independensi dalam

menjalankan profesi serta menjadi

teladan dalam menegakkan

supremasi hukum di negara

Indonesia.

\section{DAFTAR PUSTAKA :}

Adnan Buyung Nasution, Tonggak Sejarah Perjuangan Profesi Advokat, Munas Ikadin, Semarang, 3 - 5 Maret 2003.

Barda Nawawi Arief, Bunga Rampai Kebijakan Pidana, Citra Aditya Bakti, Bandung, 1996.

Frans H. Winarta, Kemandirian Advokat Dalam Undang-Undang Advokat, Bahan Seminar, 12 April 2003, Surabaya.

Moeljanto, Azas-azas Hukum Pidana, Gadjah Mada University Press, Yogyakarta, 1982.

Muladi dan Dwija Pryatno, Pertanggungiawaban Korporasi dalam Hukum Pidana, STH. Bandung, Bandung, 1992.

Roeslan Saleh, Perbuatan Pidana dan Pertanggungjawaban Pidana, Dua
Pengertian Dasar dalam Hukum Pidana, Aksara Baru, Jakarta, Cet. Ketiga, Desember 1983.

Simons dalam A.Z. Abidin Faried, Bunga Rampai Hukum Pidana, Pradnya Paramita, Jakarta, 1983.

Sudarto, Hukum dan Perkembangan Masyarakat, Sinar Baru, Bandung, 1983.

Undang-Undang Nomor : 18 Tahun 2003, tentang Profesi Advokat, pasal 1 ayat 1 .

Harian Pagi Jawa Pos, Jumat, tanggal 21 Februari 2003, hal. 3, kolom 4-7. 